Molecules 2006, 11, 64-71

molecules

ISSN 1420-3049

http://www.mdpi.org

\title{
An Efficient Scalable Synthesis of 2,3-Epoxypropyl Phenylhydrazones
}

Vytautas Getautis*, Maryte Daskeviciene, Tadas Malinauskas, Albina Stanisauskaite and Jolanta Stumbraite

Department of Organic Chemistry, Kaunas University of Technology, LT-50270 Kaunas, Lithuania Tel. (370)-37-300196, Fax (370)-37-300152

* Author to whom correspondence should be addressed; e-mail: vytautas.getautis@ktu.lt

Received: 3 January 2005; in revised form: 16 December 2005 / Accepted: 17 December 2005 /

Published: 31 January 2006

\begin{abstract}
A series of mono and di- $N$-2,3-epoxypropyl $N$-phenylhydrazones have been prepared on a large scale by reaction of the corresponding $N$-phenylhydrazones of 9-ethyl-3-carbazolecarbaldehyde, 9-ethyl-3,6-carbazoledicarbaldehyde, 4-dimethylamino-, 4-diethylamino-, 4-benzylethylamino-, 4-(diphenylamino)-, 4-(4,4'-dimethyldiphenylamino)-, 4-(4-formyldiphenylamino)- and 4-(4-formyl-4'methyldiphenylamino)benzaldehyde with epichlorohydrin in the presence of $\mathrm{KOH}$ and anhydrous $\mathrm{Na}_{2} \mathrm{SO}_{4}$.
\end{abstract}

Keywords: Heterocycles, epichlorohydrin, hydrazones, charge transport.

\section{Introduction}

Epoxides are versatile intermediates in organic synthesis; and a large variety of reagents are known for the ring opening of these compounds to yield products with important biological activities and pharmacological properties [1,2]. On the other hand, hydrazine derivatives are nowadays of considerable technical and commercial importance [3]. Particularly hydrazones are often mentioned among the most effective charge transporting low-molecular-weight materials used in electrophotography, due to their excellent hole-transporting properties and relatively simple synthesis [4-7].

Recently, we have reported the synthesis and properties of new hole transporting materials consisting of two hydrazone branches. These materials were synthesized by connecting two $N-2,3-$ 
epoxypropyl $\mathrm{N}$-phenylhydrazones with various difunctional nucleophilic compounds. The molecular structure of these transporting materials makes crystallization in the solid state difficult, so these materials are able to form glasses. Another peculiarity of the branched hydrazones is the presence of two hydroxyl groups in the molecule that improves their adhesion to some substrates and compatibility with some polymers, such as polyvinylbutyraldehyde. A variety of these branched hydrazones, involving $N$-ethylcarbazole, $N, N$-diethylaniline, $N, N$-benzylethylaniline and triphenylamine moieties have been generated [8,9]. Moreover, a new class of polymeric hydrazones was reported [10]. They ensure rapid charge transporting ability, high photosensitivity and durability of EPL, however until now there was no data concerning the synthesis of the epoxypropyl phenylhydrazones of arylaldehydes, which are the starting materials for preparation of above described novel electronactive molecules.

In this paper we report a synthetic method for large scale preparations of 2,3-epoxypropyl- $N$ phenyl-hydrazones and their bis-analogues containing 9-ethylcarbazole, diethylaniline, benzylethylaniline, triphenylamine, methyltriphenylamine, dimethyltriphenylamine moieties, which have been recently mentioned among the most usable organic photoconductors [11-14].

\section{Results and Discussion}

At first the reaction of phenylhydrazones with epichlorohydrin was carried out at room temperature in the presence of potassium hydroxide and anhydrous $\mathrm{K}_{2} \mathrm{CO}_{3}$ and lasted for 3 days. More attractive seemed the alkylation at $55-60{ }^{\circ} \mathrm{C}$ which allows to obtain various $\mathrm{N}$-2,3-epoxypropylated hydrazones. At the elevated temperature the reaction time was reduced to $1.5-2 \mathrm{~h}$, and high yields (57-81\%) were observed.

The experiments carried out revealed that this method was not suitable for bigger than preparative scale synthesis. At $55-60{ }^{\circ} \mathrm{C}$ in the presence of $\mathrm{KOH}$ and anhydrous $\mathrm{K}_{2} \mathrm{CO}_{3}$ the reaction often slipped out of control due to the polymerization of epichlorohydrin. Some changes to this method were made: the reaction was carried out at $35-40{ }^{\circ} \mathrm{C}$ by adding $\mathrm{KOH}$ and dewatering material in three portions with prior cooling of the reaction mixture to $20-25^{\circ} \mathrm{C}$, the anhydrous $\mathrm{K}_{2} \mathrm{CO}_{3}$ was replaced by anhydrous $\mathrm{Na}_{2} \mathrm{SO}_{4}$. These changes enabled to decrease the amount of the water adsorbent used, reduce the amount of poly(epichlorohydrin) formed and ensure better reaction control.

Based on the developed method, by interaction of $\mathrm{N}$-phenylhydrazones of 9-ethyl-3-carbazolecarbaldehyde, 4-dimethylamino-, 4-diethylamino-, 4-benzylethylamino-, 4-(diphenylamino)-, 4-(4,4'dimethyldiphenylamino)benzaldehydes with epichlorohydrin (Scheme 1) a series of N-2,3epoxypropyl hydrazones were synthesized on large scale with 78-90 \% yields. This series included 1(9-ethyl-carbazol-3-ylmethylene)-2-(2,3-epoxypropyl)-2-phenylhydrazine (1a), 2-(2,3-epoxypropyl)1-(4-dimethylaminophenylmethylene)-2-phenylhydrazine $\quad$ (1b), 2-(2,3-epoxypropyl)-1-(4diethylamino-phenylmethylene)-2-phenylhydrazine (1c), 1-(4-benzylethylaminophenylmethylene)-2(2,3-epoxy-propyl)-2-phenylhydrazine

(1d), epoxypropyl)-2-phenylhydrazine (1e) 1-[4-(diphenylamino)phenylmethylene]-2-(2,3and 
Scheme 1. Synthetic route to the epoxides 1a-i containing hydrazone moieties

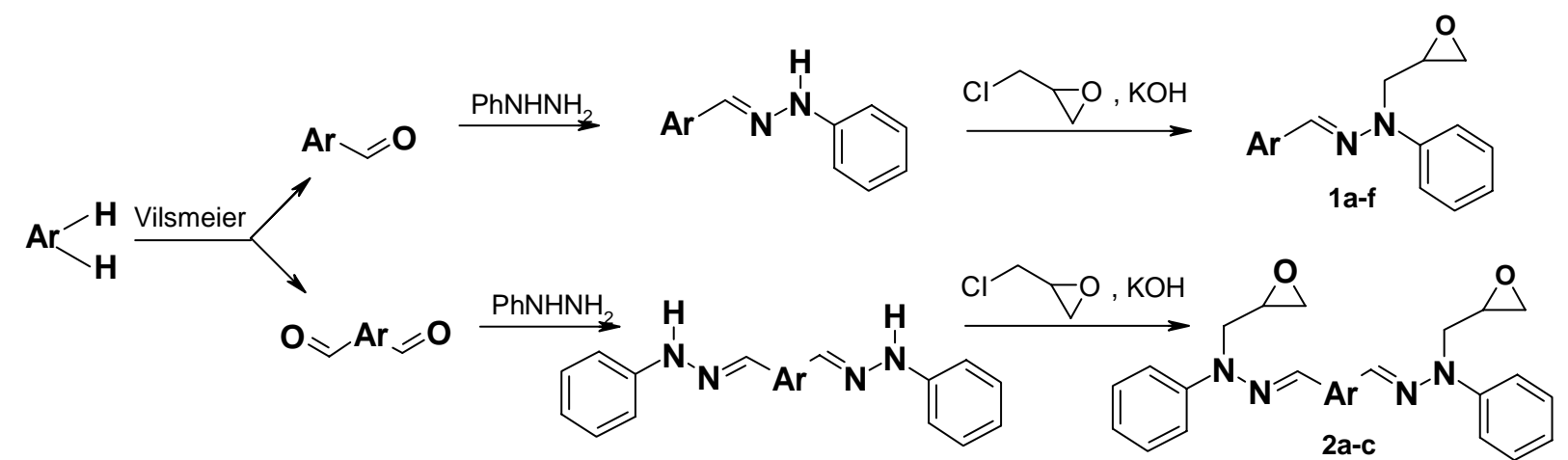

(a)

This method was slightly modified in the case of bis( $N$-2,3-epoxypropyl- $N$-phenyl)hydrazones 2a-c; the amounts of epichlorohydrin, $\mathrm{KOH}$ and anhydrous $\mathrm{Na}_{2} \mathrm{SO}_{4}$ were increased, as well as the reaction times. 9-Ethyl-3,6-carbazoledicarbaldehyde bis( $N$-2,3-epoxypropyl- $N$-phenyl)hydrazone (2a), 4-(4-formyldiphenylamino)benzaldehyde bis( $N$-2,3-epoxypropyl- $N$-phenyl)hydrazone (2b) and 4-(4'formylmethyldiphenylamino)benzaldehyde bis( $N$-2,3-epoxypropyl- $N$-phenyl)hydrazone (2c) were thus synthesized on a large scale in 50-60\% yields.

The structures of 1a-i were confirmed by their ${ }^{1} \mathrm{H}-\mathrm{NMR}$ spectra and elemental analysis data. A typical set of lines for the epoxypropyl group appears in the 4.40-2.50 ppm region of the ${ }^{1} \mathrm{H}-\mathrm{NMR}$ spectra of 1a-f and 2a-c. In the ${ }^{1} \mathrm{H}-\mathrm{NMR}$ spectrum of 1e (shown in Figure 1) we observed the most clearly defined $\mathrm{ABX}$ systems of the non-equivalent geminal protons of $\mathrm{NCH}_{2}$ and $\mathrm{CH}_{2} \mathrm{O}$. Thus the $\mathrm{CH}_{2} \mathrm{O}$ appeared as a doublet of doublets at $2.62 \mathrm{ppm}\left(\mathrm{H}_{\mathrm{A}}\right.$ with $\left.J_{\mathrm{AB}}=4.8 \mathrm{~Hz}, J_{\mathrm{AX}}=2.7 \mathrm{~Hz}\right)$ and as a doublet of doublets at $2.84 \mathrm{ppm}\left(\mathrm{H}_{\mathrm{B}}\right.$ with $\left.J_{\mathrm{BX}}=4.1 \mathrm{~Hz}\right)$ due to the coupling with $\mathrm{CH}$, while protons of $\mathrm{NCH}_{2}$ respectively gave dd at $4.35 \mathrm{ppm}\left(\mathrm{H}_{\mathrm{A}^{\prime}}\right.$ with $\left.J_{\mathrm{A}^{\prime} \mathrm{B}^{\prime}}=16.4 \mathrm{~Hz}, J_{\mathrm{A}^{\prime} \mathrm{X}}=2.4 \mathrm{~Hz}\right)$ and dd at $3.99 \mathrm{ppm}\left(\mathrm{H}_{\mathrm{B}^{\prime}}\right.$ with $J_{\mathrm{B}^{\prime} \mathrm{X}}=4.1 \mathrm{~Hz}$ ). 
Figure 1. Signals of the 2,3-epoxypropyl group in the ${ }^{1} \mathrm{H}-\mathrm{NMR}$ spectra of $\mathbf{1 e}\left(250 \mathrm{MHz}, \mathrm{CDCl}_{3}\right)$.

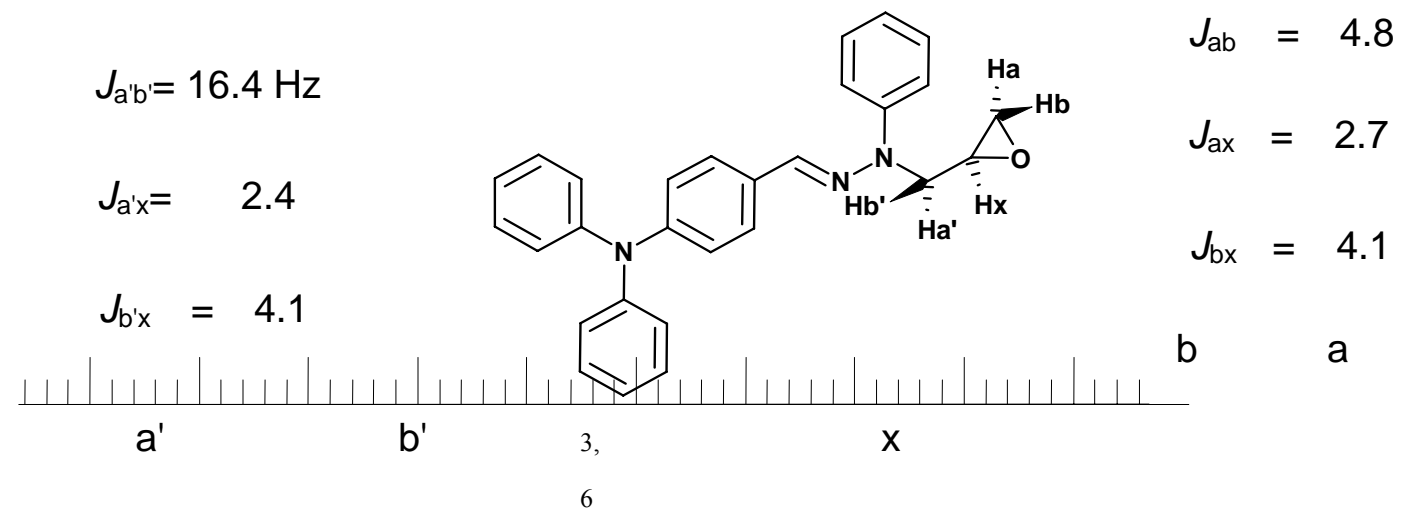

\section{Conclusions}

We have developed an efficient scalable method for the preparation of $N$-2,3-epoxypropylated $N$ phenylhydrazones 1a-f and bis( $N$-2,3-epoxypropyl- $N$-phenyl)hydrazones 2a-c, which are precursors for organic photoconductors $[8,9,12,14]$ and therefore are of potential commercial importance.

\section{Acknowledgements}

Financial support of this research by the Lithuanian Science and Studies Foundation (B-18/2005) are gratefully acknowledged.

\section{Experimental}

\section{General}

All chemicals were purchased from Aldrich and used as received without further purification, except for 4-benzylethylaminobenzaldehyde, 9-ethyl-3,6-carbazoldicarboxaldehyde, 4-(4-formyldiphenylamino)benzaldehyde and 4-(4-formyl-4'-methyldiphenylamino)benzaldehyde, which were synthesized by well known Vilsmeier reaction [15]. The ${ }^{1} \mathrm{H}-\mathrm{NMR}$ spectra were taken on a Gemini2000 (300 MHz), Bruker AC 250 (250 MHz), Mercury-VX (400 MHz) or TESLA 487C (80 MHz) NMR spectrometer. The course of the reactions and purity of the products were monitored by thinlayer chromatography on Silufol UV-254 plates using 2:1 diethylether-hexane as the eluent and visualization with iodine vapor or UV light. Silica gel (grade 62, 60-200 mesh, $150 \AA$ A, Aldrich) was used for column chromatography. 
General method for the preparation of aldehyde mono- and diphenylhydrazones

Phenylhydrazine $(0.1 \mathrm{~mol}$ for monohydrazones or $0.25 \mathrm{~mol}$ in case of dihydrazones $)$ and the corresponding aldehyde $(0.1 \mathrm{~mol})$ were dissolved in 2-propanol $(100 \mathrm{~mL})$ in case of hydrazones or THF $(100 \mathrm{~mL})$ in the case of dihydrazones. The mixture was refluxed until the aldehyde disappeared (10 $\mathrm{min})$. At the end of the reaction, the mixture was cooled to room temperature. The crystals formed upon standing were filtered off and washed with 2-propanol to give corresponding phenylhydrazones, which were subjected to the reaction with epichlorohydrin without further purification.

\section{General method of the preparation of N-2,3-epoxypropylated phenylhydrazones 1a-f}

To the mixture of phenylhydrazone of the corresponding aldehyde $(1 \mathrm{~mol})$ and epichlorohydrin $(1.5 \mathrm{~mol})$, powdered $85 \%$ potassium hydroxide $(3 \mathrm{~mol})$ and anhydrous $\mathrm{Na}_{2} \mathrm{SO}_{4}(0.4 \mathrm{~mol})$ were added in three portions with prior cooling of the reaction mixture to $20-25{ }^{\circ} \mathrm{C}\left(1^{\text {st }}\right.$ portion $-1 / 2$ of $\mathrm{Na}_{2} \mathrm{SO}_{4}$ and $1 / 3$ of $\mathrm{KOH} ; 2^{\text {nd }}$ portion $-1 / 4$ of $\mathrm{Na}_{2} \mathrm{SO}_{4}$ and $1 / 3$ of $\mathrm{KOH}$ after $1 \mathrm{~h}$ from the beginning of the reaction; $3^{\text {rd }}-1 / 4$ of $\mathrm{Na}_{2} \mathrm{SO}_{4}$ and $1 / 3$ of $\mathrm{KOH}$ after $2 \mathrm{~h}$ from the beginning of the reaction). The reaction mixture was stirred vigorously at $35-40{ }^{\circ} \mathrm{C}$ until the starting hydrazone disappeared $(3-4 \mathrm{~h})$. After termination of the reaction, the mixture was cooled to RT and filtered off. The organic layer was washed with distilled water until the wash water was neutral. The organic layer was dried over anhydrous magnesium sulfate, treated with activated charcoal, filtered and excess of epiclorohydrin was removed. In the case of 1a-d the obtained residue was dissolved in a 1:1 mixture of toluene and 2propanol. The crystals formed upon standing were filtered off and washed with 2-propanol. Compounds 1e,f were purified by column chromatography.

1-(9-ethylcarbazol-3-ylmethylene)-2-(2,3-epoxypropyl)-2-phenylhydrazine (1a): Yield 78.5 \%, m.p. 136-137 ${ }^{\circ} \mathrm{C}$ (recrystallized from toluene); ${ }^{1} \mathrm{H}-\mathrm{NMR}$ spectrum $\left(\mathrm{CDCl}_{3}, \delta, 250 \mathrm{MHz}\right): 8.35$ (s, $1 \mathrm{H}, 4-$ $\left.\mathrm{H}_{\mathrm{Ht}}\right) ; 8.14\left(\mathrm{~d}, J=7,8 \mathrm{~Hz}, 1 \mathrm{H}, 1-\mathrm{H}_{\mathrm{Ht}}\right) ; 7.93\left(\mathrm{~d}, J=7,6 . \mathrm{Hz}, 1 \mathrm{H}, 2-\mathrm{H}_{\mathrm{Ht}}\right) ; 7.90(\mathrm{~s}, 1 \mathrm{H}, \mathrm{CH}=\mathrm{N}) ; 7.54-7.20(\mathrm{~m}$, $8 \mathrm{H}, \mathrm{Ph}, \mathrm{Ht}$ ); 6.96 (t, J=7.2 Hz, 1H, 4- $\mathrm{H} \mathrm{Ph}) ; 4.37$ (m, 3H, $\underline{\mathrm{H}}_{2} \mathrm{CH}_{3}$, one of the $\mathrm{NCH}_{2}$ protons); 4.04 (dd, $J_{1}=4.3 \mathrm{~Hz}, J_{2}=16.4 \mathrm{~Hz}, 1 \mathrm{H}$, next of the $\mathrm{NCH}_{2}$ protons); $3.32(\mathrm{~m}, 1 \mathrm{H}, \mathrm{CH}) ; 2.88(\mathrm{dd}, 1 \mathrm{H}$, part of the ABX system, cis- $\mathrm{H}_{\mathrm{A}}$ of $\left.\mathrm{CH}_{2} \mathrm{O}, J_{\mathrm{AX}}=2.6 \mathrm{~Hz}, J_{\mathrm{AB}}=4.9 \mathrm{~Hz}\right) ; 2.69(\mathrm{dd}, 1 \mathrm{H}$, part of the ABX system, trans$\mathrm{H}_{\mathrm{B}}$ of $\left.\mathrm{CH}_{2} \mathrm{O}, J_{\mathrm{BX}}=4.0 \mathrm{~Hz}\right) ; 1.44\left(\mathrm{t}, J=7.2 \mathrm{~Hz}, 3 \mathrm{H}, \mathrm{CH}_{3}\right) \mathrm{ppm}$; Anal. Calcd. for $\mathrm{C}_{24} \mathrm{H}_{23} \mathrm{~N}_{3} \mathrm{O}: \mathrm{C}, 78.02$; H, 6.27; N, 11.37. Found: C, 78.12; H, 6.18; N, 11.38 .

2-(2,3-epoxypropyl)-1-(4-dimethylaminophenyl-methylene)-2-phenylhydrazine (1b): Yield 86.4 \%; m.p. 123.5-124.5 ${ }^{\circ} \mathrm{C}$ (recrystallized from 2-propanol); ${ }^{1} \mathrm{H}-\mathrm{NMR}\left(\mathrm{CDCl}_{3}, \delta, 80 \mathrm{MHz}\right)$ : 7.7-6.8 (m, 8H, $\mathrm{CH}=\mathrm{N}, \mathrm{Ar}) ; 6.7$ (d, 2H, part of $\mathrm{AB}$ system, $p-\mathrm{Ph}) ; 4.5-3.7\left(\mathrm{~m}, 2 \mathrm{H}, \mathrm{NCH}_{2}\right) ; 3.4-3.1(\mathrm{~m}, 1 \mathrm{H}, \mathrm{CH}) ; 2.9(\mathrm{~s}$, $\left.6 \mathrm{H}, \mathrm{CH}_{3}\right) ; 2.9-2.7\left(\mathrm{~m}, 1 \mathrm{H}\right.$, cis- $\mathrm{H}$ of $\left.\mathrm{CH}_{2} \mathrm{O}\right) ; 2.7-2.5\left(\mathrm{~m}, 1 \mathrm{H}\right.$, trans- $\mathrm{H}$ of $\left.\mathrm{CH}_{2} \mathrm{O}\right)$ ppm; Anal. Calcd. for $\mathrm{C}_{18} \mathrm{H}_{21} \mathrm{~N}_{3} \mathrm{O}: \mathrm{C}, 73.19 ; \mathrm{H}, 7.17 ; \mathrm{N}, 14.23$. Found: C, 73.15; H, 7.19; N, 14.31.

2-(2,3-epoxypropyl)-1-(4-diethylaminophenylmethylene)-2-phenylhydrazine (1c): Yield 80.4 \%; m.p. 79-80.5 ${ }^{\circ} \mathrm{C}$ (recrystallized from ethyl ether); ${ }^{1} \mathrm{H}-\mathrm{NMR}\left(\mathrm{CDCl}_{3}, \delta, 250 \mathrm{MHz}\right): 7.7-6.7$ (m, 8H, Ar, $\mathrm{CH}=\mathrm{N}) ; 6.6(\mathrm{~d}, 2 \mathrm{H}, 2-\mathrm{H}, 6-\mathrm{H}$ of $p-\mathrm{Ph}) ; 4.4-3.6\left(\mathrm{~m}, 2 \mathrm{H}, \mathrm{NC}_{2} \mathrm{CH}\right) ; 3.6-3.0\left(\mathrm{~m}, 5 \mathrm{H}, \underline{\mathrm{C}}_{2} \mathrm{CH}_{3}\right.$, 
$\mathrm{CH}_{2} \mathrm{CHCH}_{2}$ ); 2.75 (m, 1H, $\mathrm{ABX}$, cis- $\mathrm{H}_{\mathrm{A}}$ of $\left.\mathrm{CH}_{2} \mathrm{O}\right) ; 2.55$ (m, $\mathrm{ABX}$, trans- $\mathrm{H}_{\mathrm{B}}$ of $\left.\mathrm{CH}_{2} \mathrm{O}\right) ; 1.1(\mathrm{t}, J=7.0$ $\mathrm{Hz}, 6 \mathrm{H}, \mathrm{CH}_{3}$ ) ppm; Anal. Calcd. for $\mathrm{C}_{20} \mathrm{H}_{25} \mathrm{~N}_{3} \mathrm{O}: \mathrm{C}, 74.27 ; \mathrm{H}, 7.79 ; \mathrm{N}, 12.99$. Found: $\mathrm{C}, 74.21 ; \mathrm{H}$, $7.70 ; \mathrm{N}, 12.91$.

1-(4-benzylethylaminophenylmethylene)-2-(2,3-epoxypropyl)-2-phenylhydrazine (1d): Yield of oily 1d $80.4 \%$; ${ }^{1} \mathrm{H}-\mathrm{NMR}\left(\mathrm{CDCl}_{3}, \delta, 400 \mathrm{MHz}\right): 7.70(\mathrm{~s}, 1 \mathrm{H}, \mathrm{CH}=\mathrm{N}) ; 7.55$ (d, 2H, J=8.8 Hz, 2,6-H $\left.\mathrm{H}_{p-\mathrm{Ph}}\right)$; 7.16$7.41(\mathrm{~m}, 4 \mathrm{H}, \mathrm{Ar}) ; 6.93\left(\mathrm{t}, 1 \mathrm{H}, J=7.3 \mathrm{~Hz}, 4-\mathrm{H}_{\mathrm{Ph}}\right) ; 6.69$ (d, 2H, J=8.8 Hz, 3,5- $\left.\mathrm{H}_{p-\mathrm{Ph}}\right) ; 4.58(\mathrm{~s}, 2 \mathrm{H}$, $\left.\mathrm{CH}_{2} \mathrm{Ph}\right) ; 4.37\left(\mathrm{dd}, 1 \mathrm{H}, \mathrm{ABX}, J_{\mathrm{AB}}=16.2, J_{\mathrm{AX}}=2.4 \mathrm{~Hz}, \mathrm{H}_{\mathrm{A}}\right.$ of $\left.\mathrm{NCH}_{2}\right) ; 3.99$ (dd, 1H, ABX, $J_{\mathrm{BX}}=4.1 \mathrm{~Hz}$, $\mathrm{H}_{\mathrm{B}}$ of $\left.\mathrm{NCH}_{2}\right) ; 3.28\left(\mathrm{~m}, 1 \mathrm{H}, \mathrm{CH}_{\mathrm{X}}\right) ; 3.53$ (q, $\left.2 \mathrm{H}, J=7.3 \mathrm{~Hz}, \mathrm{C}_{2} \mathrm{CH}_{3}\right) ; 2.84$ (dd, $1 \mathrm{H}, \mathrm{ABX}, J_{\mathrm{AB}}=4.8 \mathrm{~Hz}$, $J_{\mathrm{AX}}=2.7 \mathrm{~Hz}$, cis $-\mathrm{H}_{\mathrm{A}}$ of $\left.\mathrm{CH}_{2} \mathrm{O}\right) ; 2.62\left(\mathrm{dd}, 1 \mathrm{H}, \mathrm{ABX}, J_{\mathrm{BX}}=4.0 \mathrm{~Hz}\right.$, trans- $\mathrm{H}_{\mathrm{B}}$ of $\left.\mathrm{CH}_{2} \mathrm{O}\right) ; 1.24(\mathrm{t}, J=7.3 \mathrm{~Hz}$, $3 \mathrm{H}, \mathrm{CH}_{2} \underline{\mathrm{C}}_{3}$ ); Anal. Calcd. for $\mathrm{C}_{25} \mathrm{H}_{27} \mathrm{~N}_{3} \mathrm{O}: \mathrm{C}, 77.89 ; \mathrm{H}, 7.06 ; \mathrm{N}, 10.90$. Found: C, 77.91; H, 7.15; N, 10.81 .

1-[4-(diphenylamino)phenylmethylene]-2-(2,3-epoxypropyl)-2-phenylhydrazine (1e): Yield 89.9 \%; m.p. 141-142.5 ${ }^{\circ} \mathrm{C}$ (recrystallized from toluene); ${ }^{1} \mathrm{H}-\mathrm{NMR}\left(\mathrm{CDCl}_{3}, \delta, 250 \mathrm{MHz} 250\right)$ : 7.65-6.98 (m, $19 \mathrm{H}, \mathrm{CH}=\mathrm{N}, \mathrm{Ar}) ; 6.93\left(\mathrm{t}, J=7.2 \mathrm{~Hz}, 1 \mathrm{H}, 4-\mathrm{H}_{\mathrm{Ph}}\right) ; 4.35$ (dd, $1 \mathrm{H}$, part of the ABX system, $\mathrm{H}_{\mathrm{A}}$ of $\mathrm{NCH}_{2}$, $\left.J_{\mathrm{AX}}=2.4 \mathrm{~Hz}, J_{\mathrm{AB}}=16.4\right) ; 3.99\left(\mathrm{dd}, 1 \mathrm{H}\right.$, part of the $\mathrm{ABX}$ system, $\mathrm{H}_{\mathrm{B}}$ of $\left.\mathrm{NCH}_{2}, J_{\mathrm{BX}}=4.1 \mathrm{~Hz}\right) ; 3.26(\mathrm{~m}$, $1 \mathrm{H}, \mathrm{CH}) ; 2.84\left(\mathrm{dd}, 1 \mathrm{H}\right.$, part of the $\mathrm{ABX}$ system, cis- $\mathrm{H}_{\mathrm{A}}$ of $\left.\mathrm{CH}_{2} \mathrm{O}, J_{\mathrm{AX}}=2.7 \mathrm{~Hz}, J_{\mathrm{AB}}=4.8 \mathrm{~Hz}\right) ; 2.62(\mathrm{dd}$, $1 \mathrm{H}$, part of the $\mathrm{ABX}$ system, trans $-\mathrm{H}_{\mathrm{B}}$ of $\mathrm{CH}_{2} \mathrm{O}, J_{\mathrm{BX}}=4.1 \mathrm{~Hz}$ ); Anal. Calcd. for $\mathrm{C}_{28} \mathrm{H}_{25} \mathrm{~N}_{3} \mathrm{O}: \mathrm{C}, 80.16$; H, 6.01; N, 10.02. Found: C, 80.19; H, 6.10; N, 10.09.

2-(2,3-epoxypropyl)-1-[4-(4,4'dimethyldiphenylaminophenylmethylene]-2-phenylhydrazine (1f): Yield of oily 1 ff $87.3 \%$; ${ }^{1} \mathrm{H}-\mathrm{NMR}\left(\mathrm{CDCl}_{3}, \delta, 250 \mathrm{MHz}\right)$ : $7.62(\mathrm{~s}, 1 \mathrm{H}, \mathrm{CH}=\mathrm{N}) ; 7.55-6.90(\mathrm{~m}, 17 \mathrm{H}, \mathrm{Ar}) ; 4.34$ $\left(\mathrm{dd}, 1 \mathrm{H}\right.$, part of the $\mathrm{ABX}$ system, $\mathrm{H}_{\mathrm{A}}$ of $\left.\mathrm{NCH}_{2}, J_{\mathrm{AX}}=2.2 \mathrm{~Hz}, J_{\mathrm{AB}}=16.5\right) ; 3.98(\mathrm{dd}, 1 \mathrm{H}$, part of the ABX system, $\mathrm{H}_{\mathrm{B}}$ of $\left.\mathrm{NCH}_{2}, J_{\mathrm{BX}}=4.4 \mathrm{~Hz}\right) ; 3.27(\mathrm{~m}, 1 \mathrm{H}, \mathrm{CH}) ; 2.85\left(\mathrm{dd}, 1 \mathrm{H}\right.$, part of the ABX system, cis- $\mathrm{H}_{\mathrm{A}}$ of $\left.\mathrm{CH}_{2} \mathrm{O}, J_{\mathrm{AX}}=2.7 \mathrm{~Hz}, J_{\mathrm{AB}}=4.9 \mathrm{~Hz}\right) ; 2.63\left(\mathrm{dd}, 1 \mathrm{H}\right.$, part of the $\mathrm{ABX}$ system, trans $-\mathrm{H}_{\mathrm{B}}$ of $\mathrm{CH}_{2} \mathrm{O}$, $\left.\left.J_{\mathrm{BX}}=4.0 \mathrm{~Hz}\right) \cdot \mathrm{Ph}\right) ; 7.72(\mathrm{~s}, 1 \mathrm{H}, \mathrm{CH}=\mathrm{N})$; Anal. Calcd. for $\mathrm{C}_{30} \mathrm{H}_{29} \mathrm{~N}_{3} \mathrm{O}: \mathrm{C}, 80.51 ; \mathrm{H}, 6.53 ; \mathrm{N}, 9.39$. Found: C, 80.52; H, 6.48; N, 9.46 .

\section{General synthetic method of bis(N-2,3-epoxypropyl-N-phenyl)hydrazones 2a-c}

To the mixture of the diphenylhydrazone of the corresponding dialdehyde $(1 \mathrm{~mol})$ and epichlorohydrin $(22.5 \mathrm{~mol})$, powdered $85 \%$ potassium hydroxide $(4.5 \mathrm{~mol})$ and anhydrous $\mathrm{Na}_{2} \mathrm{SO}_{4}$ $(0.6 \mathrm{~mol})$ were added in three portions with prior cooling of the reaction mixture to $20-25{ }^{\circ} \mathrm{C}\left(1^{\text {st }}\right.$ portion $-1 / 2$ of $\mathrm{Na}_{2} \mathrm{SO}_{4}$ and $1 / 3$ of $\mathrm{KOH} ; 2^{\text {nd }}$ portion $-1 / 4$ of $\mathrm{Na}_{2} \mathrm{SO}_{4}$ and $1 / 3$ of $\mathrm{KOH}$ after $1 \mathrm{~h}$ from the beginning of the reaction; $3^{\text {rd }}-1 / 4$ of $\mathrm{Na}_{2} \mathrm{SO}_{4}$ and $1 / 3$ of $\mathrm{KOH}$ after $2 \mathrm{~h}$ from the beginning of the reaction). The reaction mixture was stirred vigorously at $35-40{ }^{\circ} \mathrm{C}$ until the starting dihydrazone disappeared (7-8 h). After completion of the reaction, the mixture was cooled to RT and filtered off. The organic part was washed with distilled water until the wash water was neutral. The organic layer was dried over anhydrous magnesium sulfate, treated with activated charcoal, filtered and the excess

of epiclorohydrin was removed. In the case of $\mathbf{2 a , b}$ the residues obtained were recrystallized from 
toluene and the crystals formed upon standing were filtered off and washed with 2-propanol. Compound 2c was purified by column chromatography.

9-ethyl-3,6-carbazoledicarbaldehyde bis(N-2,3-epoxypropyl-N-phenyl)hydrazone (2a): Yield: $342 \mathrm{~g}$ (63 \%), m.p. 119-120 ${ }^{\circ} \mathrm{C} ;{ }^{1} \mathrm{H}-\mathrm{NMR}$ spectrum (300 MHz, $\mathrm{CDCl}_{3}$ ), ppm: 8.38 (split s, 2H); 7.9-7.88 (m, $4 \mathrm{H})$; 7.49-7.43 (m, 4H); 7.40-7.32 (m, 6H); 6.96 (t, 2H, J=7.2 Hz); 4.42-4.29 (m, 6H); 4.06-3.97 (dd, $\left.2 \mathrm{H},\left(\mathrm{H}_{\mathrm{A}}\right), J_{\mathrm{AX}}=4.5 \mathrm{~Hz}, J_{\mathrm{AB}}=16.4 \mathrm{~Hz}\right) ; 3.31(\mathrm{~m}, 2 \mathrm{H}) ; 2.90-2.85\left(\mathrm{dd}, 2 \mathrm{H},\left(\mathrm{H}_{\mathrm{A}}\right), J_{\mathrm{AX}}=3.9 \mathrm{~Hz}\right) ; 2.70-2.65$ $\left(\mathrm{dd}, 2 \mathrm{H},\left(\mathrm{H}_{\mathrm{B}}\right), J_{\mathrm{BX}}=2.7 \mathrm{~Hz} ; J_{\mathrm{AB}}=5.1 \mathrm{~Hz}\right) ; 1.43(\mathrm{t}, J=7.2 \mathrm{~Hz})$; Anal. Calcd for $\mathrm{C}_{34} \mathrm{H}_{33} \mathrm{~N}_{5} \mathrm{O}_{2} \%$ : C 75.11; H 6.12; N 12.88. Found, \%: C 75.16; H 6.09; N 12.81 .

4-(4-formyldiphenylamino)benzaldehyde bis(N-2,3-epoxypropyl-N-phenyl)hydrazone (2b): Yield: 312 g (52 \%), m.p. 163.5-165 ${ }^{\circ} \mathrm{C}$; ${ }^{1} \mathrm{H}-\mathrm{NMR}$ spectrum (300 MHz, $\left.\mathrm{CDCl}_{3}\right)$, ppm: 7.63 (s, 2H); 7.62-7.56 (m, $4 \mathrm{H}) ; 7.43-7.02(\mathrm{~m}, 17 \mathrm{H}) ; 6.94(\mathrm{t}, 2 \mathrm{H}, J=7.1 \mathrm{~Hz}) ; 4.40-4.30\left(\mathrm{dd}, 2 \mathrm{H},\left(\mathrm{H}_{\mathrm{A}}\right), J_{\mathrm{AX}}=2.1 \mathrm{~Hz}, J_{\mathrm{AB}}=16.5 \mathrm{~Hz}\right)$; 4.02-3.92 (dd, 2H, $\left.\left(\mathrm{H}_{\mathrm{B}}\right), J_{\mathrm{BX}}=4.2 \mathrm{~Hz}\right) ; 3.26(\mathrm{~m}, 2 \mathrm{H}) ; 2.84\left(\mathrm{dd}, 2 \mathrm{H},\left(\mathrm{H}_{\mathrm{A}}\right), J_{\mathrm{AX}}=4.2 \mathrm{~Hz}, J_{\mathrm{AB}}=5.1 \mathrm{~Hz}\right)$; 2.65-2.60 (dd, $\left.\left(\mathrm{H}_{\mathrm{B}}\right), J_{\mathrm{BX}}=2.7 \mathrm{~Hz}\right)$; Anal. Calcd for $\mathrm{C}_{38} \mathrm{H}_{35} \mathrm{~N}_{5} \mathrm{O}_{2} \%$ : C 76.87; H 5.94; N 11.80. Found, $\%$ : C 76.71; H 5.91; N 11.70 .

4-(4-formyl-4'-methyldiphenylamino)benzaldehyde bis(N-2,3-epoxypropyl-N-phenyl)hydrazone (2c): Yield of amorphous 2c: $332 \mathrm{~g} \mathrm{(55 \% );}{ }^{1} \mathrm{H}-\mathrm{NMR}$ spectrum $\left(300 \mathrm{MHz}, \mathrm{CDCl}_{3}\right)$, ppm: 7.63 (s, 2H); 7.61$7.54(\mathrm{~m}, 4 \mathrm{H}) ; 7.42-7.02(\mathrm{~m}, 17 \mathrm{H}) ; 6.94(\mathrm{t}, 2 \mathrm{H}, J=7.2 \mathrm{~Hz}) ; 4.40-4.28\left(\mathrm{dd}, 2 \mathrm{H},\left(\mathrm{H}_{\mathrm{A}}\right), J_{\mathrm{AX}}=2.1 \mathrm{~Hz}, J_{\mathrm{AB}}=\right.$ $16.5 \mathrm{~Hz}) ; 4.02-3.90\left(\mathrm{dd}, 2 \mathrm{H},\left(\mathrm{H}_{\mathrm{B}}\right), J_{\mathrm{BX}}=4.2 \mathrm{~Hz}\right) ; 3.26(\mathrm{~m}, 2 \mathrm{H}) ; 2.84\left(\mathrm{dd}, 2 \mathrm{H},\left(\mathrm{H}_{\mathrm{A}}\right), J_{\mathrm{AX}}=4.2 \mathrm{~Hz}, J_{\mathrm{AB}}=\right.$ $4.8 \mathrm{~Hz}) ; 2.66-2.60\left(\mathrm{dd},\left(\mathrm{H}_{\mathrm{B}}\right), J_{\mathrm{BX}}=2.7 \mathrm{~Hz}\right) ; 2.33(\mathrm{~s}, 3 \mathrm{H})$; Anal. Calcd for $\mathrm{C}_{39} \mathrm{H}_{37} \mathrm{~N}_{5} \mathrm{O}_{2} \%$ : C $77.08 ; \mathrm{H}$ $6.14 ;$ N 11.52. Found, \%: C 77.14; H 6.10; N 11.58.

\section{References}

1. Luly, J. R.; Yi, N.; Soderquist, J.; Stein, H.; Cohen, J.; Perun, T. J.; Plattner, J. J. J. Med. Chem. 1987, 30, 1609.

2. Corey, E. J.; Clark, D. A.; Goto, G.; Marfat, A.; Mioskowski, C.; Samuelsson, B.; Hammarstrom, S. J. Am. Chem. Soc. 1980, 102, 3663.

3. Hydrazine and its Derivatives. In: Kirk-Othmer Encyclopedia of Chemical Technology, $4^{\text {th }}$ ed; Wiley: New York, 1995; Vol. 13.

4. Mort, J.; Pfister, G. In: Electronic Properties of Polymers; Wiley: New York, 1982.

5. Döbler, M.; Weder, C.; Neuenshwander, P.; Suter, U.W. Macromolecules 1998, 31, 6184.

6. Nam, H.; Kang, D.H.; Kim, J.K.; Park, S.Y. Chem. Lett. 2000, 29, 1298.

7. Ostrauskaite, J.; Voska, V.; Grazulevicius, V. Monatsh. Chem. 2002, 133, 599.

8. Getautis, V.; Paliulis, O.; Paulauskaite, I.; Gaidelis, V.; Jankauskas, V.; Sidaravicius, J.; Tokarski, Z.; Law, K.; Jubran, N. J. Imaging Sci. Technol. 2004, 48, 265.

9. Daskeviciene, M.; Gaidelis, V.; Getautis, V.; Jankauskas, V.; Paliulis, O.; Sidaravicius, J. Lith. J. Phys. 2001, 41, 521.

10. Getautis V.; Grazulevicius V. J.; Malinauskas T.; Jankauskas V.; Tokarski Z.; Jubran N. Chem. Lett. 2004, 33, 1336. 
11. Getautis, V.; Daskeviciene, M.; Stanisauskaite, P.; Paliulis, O. Chem. Heterocycl. Comp. 2002, 38,778 .

12. Gaidelis, V.; Gavutiene, J.; Getautis, V.; Grazulevicius, J.V.; Jankauskas, V.; Kavaliunas, R.; Lazauskaite, R.; Paliulis, O.; Rossman, M.A.; Sidaravicius, D.J.; Smith, D.P.; Stanisauskaite, A. US Patent 6,214,503, 2001.

13. Getautis, V.; Paliulis, O.; Degutyte, R.; Paulauskaite, I. Chem. Heterocycl. Comp. 2004, 40, 90.

14. Tokarski, Z.; Jubran, N.; Getautis, V.; Paliulis, O.; Daskeviciene, M.; Paulauskaite, I.; Jankauskas, V.; Gaidelis, V.; Sidaravicius, J. IS\&T`s NIP19: International Conference on Digital Printing Technologies 2003, 702.

15. Vilsmeier, V.; Haack, A. Ber., 1927, 60, 119

Sample Availability: Available from the authors.

(C) 2006 by MDPI (http:www.mdpi.org). Reproduction is permitted for noncommercial purposes 